\title{
Pengembangan Media Video Pembelajaran Ilmu Pengetahuan Sosial pada Siswa Sekolah Dasar
}

\author{
Friendha Yuanta \\ Pendidikan Guru Sekolah Dasar, Fakultas Bahasa dan Sains \\ Universitas Wijaya Kusuma Surabaya. \\ email: www.friendha@gmail.com
}

\begin{abstract}
Development of instructional media for learning valid and effective video learning media as a learning resource for social studies learning in grade IV elementary school. The development of this instructional video media uses the ASSURE model which has 6 stages: (1) analysis of students, (2) determining learning objectives, (3) choosing methods, media and materials, (4) using media and materials, (5) encouraging participation students, (6) evaluation and improvement. The subject of the development of this instructional video media is Grade IV students of SDN Pakis V. The development of this video media is declared valid to be used in social studies learning in class $I V$. This is obtained from the results of the validation of media experts, material experts, individual students, small groups, large groups / classical. After testing the experts and testing the students then conducted trials aimed at learning effectiveness using this instructional video media. Test results obtained in the use of instructional video media show that students have succeeded in getting grades above the specified KKM. Thus it can be denied that this instructional video learning media is effective for use in the learning process.
\end{abstract}

Keywords: media development, video learning, social studies.

\begin{abstract}
Abstrak
Pengembangan media ini bertujuan untuk menghasilkan suatu produk media video pembelajaran yang valid dan efektif sebagai salah satu sumber belajar untuk pembelajaran IPS di kelas IV SD. Pengembangan media video pembelajaran ini menggunakan model ASSURE yang mempunyai 6 tahapan yaitu : (1) analisis siswa, (2) menentukan tujuan pembelajaran, (3) memilih metode, media dan materi, (4) menggunakan media dan materi, (5) mendorong partisipasi siswa, (6) evaluasi dan perbaikan. Subyek dari pengembangan media video pembelajaran ini adalah siswa kelas IV SDN Pakis V. Pengembangan media video ini dinyatakan valid digunakan dalam pembelajaran IPS kelas IV. Hal ini diperoleh dari nilai hasil validasi ahli media, ahli materi, siswa perorangan, kelompok kecil, kelompok besar/ klasikal. Setelah dilakukan uji para ahli dan uji coba kepada siswa kemudian dilakukan post test yang bertujuan untuk mengetahui keefektifan penggunaan media video pembelajaran ini. Hasil tes yang diperoleh dalam penggunaan media video pembelajaran ini menunjukkan bahwa para siswa berhasil memperoleh nilai di atas KKM yang ditetapkan. Dengan demikan dapat disimpulkan bahwa pengembangan media video pembelajaran ini efektif untuk digunakan dalam proses pembelajaran.
\end{abstract}

Kata Kunci : Pengembangan media, Video pembelajaran, IPS. 


\section{PENDAHULUAN}

Berkembangnya teknologi saat ini memberikan pengaruh bagi dunia pendidikan, khususnya dalam media pembelajaran yang digunakan dalam proses pembelajaran. Media pembelajaran adalah sarana yang memungkinkan terwujudnya hubungan langsung antara karya seorang pengembang mata pelajaran dengan siswa (Anderson dalam Melinda, 2017). Media pembelajaran juga merupakan alat atau sumber belajar yang dapat membantu seorang guru dalam menyampaikan pesan kepada siswa. Media pembelajaran adalah segala sesuatu yang dapat digunakan untuk menyalurkan pesan yang dapat memberikan rangsangan kepada siswa sehingga terjadi interaksi mengajar tertentu (Ibrahim, 2005). Adanya media pembelajaran di sekolah membantu dalam pelaksanaan proses belajar mengajar. Pemanfaatan media pembelajaran dalam proses pembelajaran juga perlu direncanakan dan dirancang secara sistematis agar media pembelajaran efektif untuk digunakan.

Salah satu media teknologi informasi dan komunikasi yang mampu menjangkau dan paling populer di kalangan masyarakat luas adalah media video. Video juga merupakan media elektronik yang mampu menggabungkan teknologi audio dan visual secara bersama sehingga menghasilkan suatu tayangan yang dinamis dan menarik. Dengan adanya dua unsur tersebut diharapkan siswa mampu menerima, memahami, dan mengingat pesan pembelajaran. Media audio visual memiliki fungsi (1) memperjelas penyajian pesan agar tidak terlalu bersifat verbalistis, mengatasi keterbatasan ruang, waktu dan daya indra, (3) penggunaan media pendidikan secara tepat dan bervariasi dapat mengatasi sifat pasif anak didik. (Sadiman, 2009). Pemanfaatan media video dapat digunakan untuk menunjang pembelajaran di kelas, terutama di kelas bawah yaitu di sekolah dasar.

Pemanfaatan media pembelajaran yang tepat dalam proses belajar dan mengajar di kelas dapat membawa keberhasilan bagi guru maupun siswa. Selain itu peran guru sangatlah penting di dalam proses pembelajaran, guru juga dituntut untuk bisa membuat media yang kreatif dan inovatif serta dapat memanfaatkan media pembelajaran yang tersedia di sekolah. Salah satu pembelajaran yang ada di sekolah dasar adalah mata pelajaran IPS. IPS merupakan perpaduan dari sejumlah mata pelajaran seperti sejarah, geografi, ekonomi, sosiologi, dan antropologi. Perpaduan tersebut dimaksudkan untuk membiasakan anak sejak usia sekolah dasar dalam memecahkan masalah sosial dengan pendekatan secara utuh tidak terkotak-kotak dari berbagai disiplin ilmu sosial (Ruminiati, dalam Melinda 2017).

Dalam pembelajaran IPS guru dituntut untuk mengarahkan siswa mampu berfikir kritis dan kreatif. Namun dalam pembelajaran sehari-hari di sekolah sering terjadi kesulitan penyampaian materi pembelajaran IPS kepada siswa. Pemilihan metode dan media pembelajaran yang kurang sesuai menjadi salah satu penyebabnya. Pembelajaran yang digunakan oleh guru pun juga masih banyak menggunakan buku cetak dan LKS yang membuat suasana pembelajaran menjadi pasif, Siswa terlihat bosan dan kurang berminat mengikuti pembelajaran IPS. Hal ini juga dialami di kelas SDN Pakis V. 
Berdasarkan pada latar belakang tersebut maka peneliti terpacu untuk melakukan penelitan tentang pengembangan media video pembelajaran pada pembelajaran IPS. Pengembangan media ini bertujuan untuk menghasilkan suatu produk media video pembelajaran yang valid dan efektif sebagai salah satu sumber belajar untuk pembelajaran IPS di kelas IV SD.

\section{KAJIAN TEORI}

\section{Media Video Pembelajaran}

Menurut Smaldino

sebuah media adalah sebuah sarana komunikasi dan sumber informasi. Berasal dari bahasa latin yang berarti "antara", istilah tersebut merujuk pada segala sesuatu yang membawa informasi antara sumber dan penerima. Dikatakan media pembelajaran, karena segala sesuatu tersebut membawa pesan untuk suatu pembelajaran. Sedangkan istilah video berasal dari kata vidi atau visum yang artinya melihat atau mempunyai daya penglihatan. Arsyad (2013) mengemukakan bahwa pengajaran melalui audio visual adalah produksi dan penggunaan materi yang penyerapannya melalui pandangan dan pendengaran serta tidak seluruhnya tergantung kepada pemahaman kata atau simbol-simbol yang serupa. Video merupakan gambar yang bergerak dan disertai oleh suara. Media video merupakan salah satu jenis media audio visual dan dapat menggambarkan suatu objek yang bergerak dengan suara yang susuai dengan isi gambar tersebut. Peran video adalah sebagai penyaji informasi.

Media pembelajaran sebagai alat bantu dalam proses belajar dan pembelajaran yang tidak bisa dipungkiri keberadaannya. Guru sadar bahwa tanpa bantuan media, maka materi pembelajaran sulit untuk dimengerti dan dipahami oleh siswa, terutama pembelajaran yang rumit dan kompleks. Setiap materi pembelajaran mempunyai tingkat kesukaran yang bermacam-macam. Ada pembelajaran yang tidak memerlukan media pembelajaran, tetapi di lain sisi ada jg pembelajaran yang memerlukan media pembelajaran. Materi pembelajaran yang mempunyai tingkat kesulitan tinggi tentu sulit dipahami oleh siswa, apalagi oleh siswa yang kurang menyukai pembelajaran yang disampaikan.

Berkembangnya teknologi muncullah berbagai macam bahan ajar baru yang semakin canggih, mulai dari bentuk bahan ajar cetak, lalu bahan ajar audio, hingga bahan ajar audio visual atau video. Dalam perkembangan tersebut menunjukkan bahwa bahan ajar selalu mengikuti perkembangan teknologi dan ilmu pengetahuan. Pengajaran dengan menggunakan video bercirikan adanya pemakaian perangkat keras selama proses belajar, seperti proyektor film, tape recorder dan proyektor visual lebar. Jadi pembelajaran melalui video adalah produksi dan penggunaan materi yang penyerapannya melalui penglihatan dan pendengaran.

Video merupakan rekaman gambar hidup atau program televisi untuk ditayangkan lewat pesawat televisi atau dengan kata lain video merupakan tayangan gambar bergerak yang disertai dengan suara, hal ini diungkapkan dalam Kamus Besar Bahasa Indonesia. Media video merupakan salah satu media yang dapat digunakan dalam pembelajaran menyimak. Media video ini dapat menambah minat siswa dalam bekajar karena dapat menyimak sekaligus melihat gambar. Kemempuan video dapat menyajikan informasi, 
memaparkan proses, menjelaskan konsep-konsep yang rumit, mengajarkan ketrampilan, menyingkat atau memperpanjang waktu dan dapat mempengaruhi sikap.

\section{Tujuan Penggunaan Media Video}

Tujuan dari pembelajaran menggunakan media video yaitu mencakup tujuan kognitif, afektif dan psikomotor. (Anderson, 1987).

\section{Tujuan Kognitif}

\begin{tabular}{lrr} 
a. Dapat & \multicolumn{2}{c}{ mengembangkan } \\
kemampuan & kognitif yang \\
menyangkut & \multicolumn{2}{c}{ kemempuan } \\
mengenal & kembali dan \\
kemampuan & \multicolumn{2}{c}{ memberikan } \\
rangsangan & berupa gerak dan \\
sensasi & & gak
\end{tabular}

b. Dapat mempertunjukkan serangkaian gambar diam tanpa suara sebagaimana media foto dan film bingkai meskipun kurang ekonomis

c. Video dapat digunakan untuk menunjukkan contoh cara bersikap atau berbuat dalam suatu penampilan, khususnya menyangkut interaksi manusiawi.

2. Tujuan Afektif

Dengan menggunakan efek dan teknik, video dapat memjadi media yang sangat baik dalam mempengaruhi sikap dan emosi.

3. Tujuan Psikomotor

a. Video merupakan media yang tepat untuk memperlihattkan contoh ketrampilan yang menyangkut gerak. Gerakan bisa diperlambat maupun dipercepat

b. Melaui media siswa langsung mendapat umpan balik secara visual terhadap kemampuan mereka sehingga mencobe ketrampilan yang menyangkut gerakan tadi.

\section{Manfaat Penggunaan Media Video}

Manfaat penggunaan media video antara lain : (Prastowo 2012)

1. Memberikan pengalaman yang terduga kepada peserta didik.

2. Memperlihatkan secara nyata sesuatu yang pada awalnya tidak mungkin bisa dilihat.

3. Menganalisis perubahab dalam periode waktu tertentu.

4. Memberikan pengalaman kepada peserta didik untuk merasakan suatu keadaan tertentu.

5. Menampilkan presentasi studi kasus tentang kehidupan sebenarnya yang dapat memicu diskusi peserta didik.

Dengan adanya media video siswa dapat menyaksikan secara langsung suatu peristiwa yang berbahaya maupun peristiwa lampau yang tidak bisa dihadirkan di dalam kelas. Siswapun dapat memutar kembali media video sesuai kebutuhan dan keperluan mereka. Pembelajaran dengan media video menumbuhkan minat serta motivasi siswa untuk selalu memperhatikan pelajaran.

\section{Kelebihan dan Kelemahan Media Video}

Menurut Daryanto (2011) ada beberapa kelebihan dan kekurangan dalam penggunaan media video, antara lain :

1. Kelebihan

a. Video dapat menambah suatu dimensi baru di dalam pembelajaran, video menyajikan gambar bergerak kepada siswa disamping suara yang menyertainya.

b. Video dapat menampilkan suatu fenomena yang sulit untuk dilihat secara nyata.

2. Kekurangan

a. Opposition

Pengambilan yang kurang tepat dapat menyebabkan timbulnya 
keraguan penonton dalam menafsirkan gambar yang dilihatnya

b. Material pendukung

Video membutuhkan alat proyeksi untuk dapat menampilkan gambar yang ada di dalamnya

c. Budget

Untuk membuat membutuhkan biaya yang tidak sedikit.

Menurut Anderson (1987) media video memiliki kelebihan antara lain :

1. Dengan menggunakan video (disertai suara atau tidak), kita dapat menunjukkan kembali gerakan tertentu.

2. Dengan menggunakan efek tertentu dapat diperkokoh baik proses belajar maupun nilai hiburan dari penyajian itu

3. Dengan video, informasi dapat disajikan secara serentak pada waktu yang sama di lokasi (kelas) yang berbeda dan dengan jumlah penonton atau peserta yang tak terbatas dengan jalan menempatkan monitor di setiap kelas

4. Dengan video siswa dapat belajar secara mandiri.

\section{Sedangkan}

keterbatasan

penggunaan video antara lain :

1. Biaya produksi video sangat tinggi dan hanya sedikit orang yang mampu mengerjakannya

2. Layar monitor yang kecil akan membatasi jumlah penonton, kecuali jaringan monitor dan system proyeksi video diperbanyak

3. Ketika akan digunakan peralatan video harus sudah tersedia di tempat penggunaan

4. Sifat komunikasinya bersifat satu arah dan harus diimbangi dengan pencarian bentuk umpan balik yang lain.
Media pembelajaran pasti mempunyai kelebihan dan kekurangan masing-masing, begitu juga dengan media video pembelajaran. Dalam penggunaannya video tidak bisa berdiri sendiri, media video ini membutuhkan alat pendukung seperti LCD untuk memproyeksikan gambar maupun speaker aktif untuk menampilkan suara agar terdengar jelas. Penggunaan video pembelajaran ini bersifat satu arah, siswa hanya memperhatikan media video, hal inilah yang perlu diperhatikan oleh guru. Video dapat diulang-ulang maupun diberhentikan dalam pemutarannya, sehingga guru bisa mengajak komunikasi siswa tentang isi, materi maupun pesan dari video yang dilihat. Guru juga bisa mengajak siswa tanya jawab tentang video yang disimak siswa, sehingga komunikasi tersebut tidak hanya bersifat satu arah.

\section{Pembelajaran IPS SD}

Istilah IPS pada Sekolah Dasar merupakan nama mata pelajaran yang berdiri sendiri sebagai integrasi dari sejumlah konsep disiplin ilmu sosial, humaniora, sains, bahkan berbagai isu dan masalah sosial kehidupan. Materi IPS untuk jenjang sekolah dasar tidak terlihat aspek disiplin ilmu karena yang lebih dipentingkan adalah dimensi pedagogis dan psikologi serta karakterisktik kemempuan berpikir siswa yang bersifat holistik. Menurut Sapriya (2009) pendidikan IPS adalah penyederhanaan atau adaptasi dari disiplin ilmu-ilmu sosial dan humaniora, serta kegiatan dasar manusia yang diorganisasikan dan disajikan secara ilmiah dan pedagogis/psikologis.

Pendidikan IPS di SD merupakan perwujudan terdisiplinan dari berbagai ilmu sosial, yang didasari bahan kajian geografi, ekonomi, sosiologi, 
antropologi, tatanegara, dan sejarah sehingga pendidikan IPS bukanlah mata pelajaran dengan disiplin ilmu tunggal melainkan gabungan dari berbagai disiplin ilmu.

\section{Karakteristik IPS Sekolah Dasar}

IPS merupakan gabungan ilmuilmu social terintegrasi atau terpadu. Pengertian terpadu, bahwa bahan atau materi IPS diambil dari ilmu-ilmu sosial yang dipadukan dan tidak terpisah-pisah dalam kotak disiplin ilmu. (Sadeli, 1986). Berikut ini karakteristik IPS dilihat dari materi dan strategi penyampaiannya:

\section{Materi IPS}

Mempelajari IPS pada hakekatnya adalah menelaah interaksi antara individu dan masyarakat dengan lingkungan (fisik dan social budaya). Materi IPS digali dari segala aspek kehidupan praktis sehari-hari di masyarakat. Dengan demikian masyarakat dan lingkungannya, selain menjadi sumber IPS sekaligus juga menjadi laboratoriumnya. Pengetahuan konsep, teori-teori IPS yang diperoleh anak di dalam kelas dapat dicocokkan dan dicobakan sekaligus diterapkan dalam kehidupan sehari-hari di masyarakat.

2. Strategi Penyampaian Pengajaran IPS

Strategi penyampaian pengajaran IPS, sebagian besar adalah didasarkan pada suatu tradisi, yaitu materi disusun dalam urutan: anak (diri sendiri), keluarga, masyarakat/tetangga, kota, region, Negara, dan dunia. Tipe kurikulum seperti ini disebut "The Wedining Horizon or Expanding Environment Curriculum" (Mukminan, 1996). Tipe kurikulum tersebut, didasarkan pada asumsi bahwa anak pertama-tama dikenalkan atau perlu memperoleh konsep yang berhubungan dengan lingkungan terdekat atau diri sendiri. Selanjutnya secara bertahap dan sistematis bergerak dalam lingkungan konsentrasi keluar dari lingkaran tersebut, kemudian mengembangkan kemampuannya untuk menghadapi unsur-unsur dunia yang lebih luas.

\section{METODE PENELITIAN}

Pengembangan

ini menggunakan model Model Desain Pembelajaran ASSURE (Analyze learners, States objective, Select methods, media and material, Utilize, Requaire learner participation, Evaluate and Revise). Model ASSURE adalah salah satu model yang dapat menuntun siswa secara sistematis untuk merencenakan proses pembelajaran secara efektif. Model ASSURE ini merupakan model yang menekankan pada kesesuaian antara materi dengan pemilihan media dan metode yang diterapkan dalam setiap proses pembelajaran (Smaldino, 2008). Model ASSURE pada pelaksanaanya memadukan penggunaan teknologi dan media di ruang kelas. Jadi dengan melakukan perencanaan secara sistematis, dapat membantu memecahkan masalah dan membantu mempermudah menyampaikan pembelajaran. Karena proses pembelajaran itu merukapan proses yang komplek dan merupakan suatu system yang perlu dilakukan dengan endekatan sistematis.

Model ASSURE ini mempunyai 6 tahapan yaitu (1) analisis siswa, (2) menentukan tujuan pembelajaran, (3) memilih metode, media dan materi, (4) menggunakan media dan materi, (5) mendorong partisipasi siswa, (6) evaluasi dan perbaikan. 


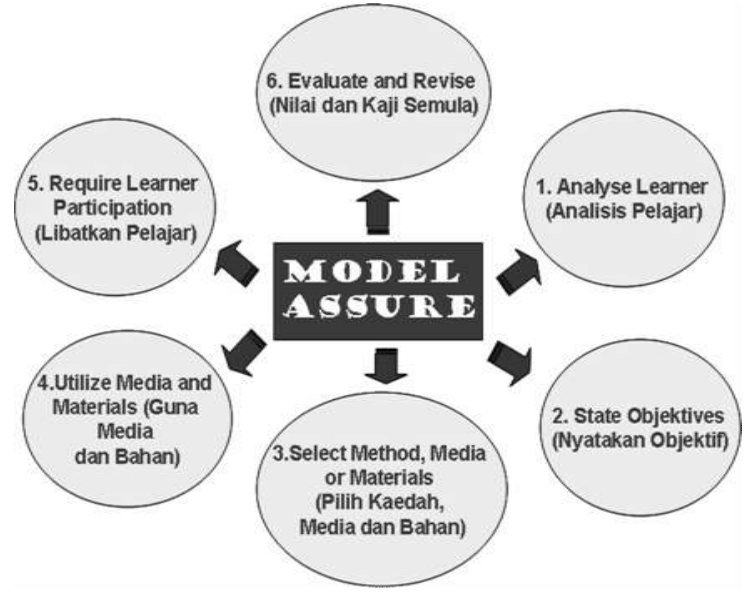

Gambar 1. Model ASSURE

Model Assure mempunyai beberapa tahapan yaitu:

1. Langkah pertama dalam merencanakan ruang kelas adalah dengan mengidentifikasi dan menganalisis karakteristik siswa yang disesuaikan dengan hasil belajar. Yang perlu diperhatikan adalah karakteristik umum, kompetensi dasar spesifik seperti pengetahuan, kemampuan dan sikap serta memperhatikan gaya belajar

2. Langkah kedua dengan menyatakan standart dan tujuan pembelajaran yang spesifik untuk kegiatan yang dilakukan. Tujuan yang dinyatakan dengan baik akan memperjelas tujuan, perilaku yang diinginkan, kondisi dan kinerja yang akan diamati dan tingkat pengetahuan atau kemempuan baru akan dikuasai siswa.

3. Langkah ketiga setelah menganalisis dan menyatakan standar dan tujuan pembelajaran, maka tugas selanjutnya adalah membangun jembatan diantara kedua titik tersebut dengan memilih strategi pengajaran, teknologi dan media yang disesuaikan, serta memutuskan materi yang diberikan.

4. Langkah keempat adalah dengan melibatkan peran siswa untuk menggunakan teknologi, strategi dan materi untuk membantu siswa mencapai tujuan pembelajaran dengan melibatkan guru sebagai fasilitator.

5. Langkah kelima dengan melibatkan partisipasi siswa. Aktifitas yang terjadi memungkinkan siswa menerapkan pengetahuan atau kemampuan baru dan menerima umpan balik

6. Langkah keenam adalah mengevaluasi dan merevisi. Setelah pelaksanaan pembelajaran di kelas, penting untuk mengevaluasi dampak kegiatan yang telah berlangsung terhadap siswa. Penilaian sebaiknya tidak memeriksa tingkat dimana siswa dapat mencapai tujuan pembelajaran, namun juga memeriksa keseluruhan proses pengajaran dan dampak penggunaan media. Hal ini dapat dicocokkan antara tujuan belajar dan hasil pembelajaran.

Media video ini setelah dikembangkan atau di produksi maka langkah selanjutnya adalah diuji cobakan melalui 2 tahap yaitu uji coba validasi dan uji coba produk. Uji coba validasi dilakukan oleh ahli media dan ahli isi/materi khususnya pelajaran IPS. Produk video pengembangan ini akan diuji cobakan dan terdapat saran-saran yang harus diperbaiki agar bisa menghasilkan produk yang benar-benar valid oleh ahli media dan ahli isi/materi. Sedangkan uji coba produk melalui 3 tahapan yaitu uji coba perorangan, uji coba kelompok kecil yang terdiri dari 5 siswa, dan uji coba kelompok besar/klasikal yang terdiri dari 30 siswa. Uji coba ini dilakukan di SDN Pakis V. Tes yang dilakukan 
untuk uji coba siswa yaitu post tes hasil pembelajaran menggunakan media video pada pembelajaran IPS.

\section{HASIL DAN PEMBAHASAN}

Hasil dari penelitian menunjukkan bahwa guru mempunyai keinginan untuk mengembangkan media pembelajaran yang efektif dan inovatif sehingga mampu merangsang keaktifan siswa, merangsang kreatifitas dan dapat meningkatkan prestasi belajar para siswa. Namun dalam pembelajaran sehari-hari di sekolah sering terjadi kesulitan penyampaian materi pembelajaran IPS kepada siswa. Pemilihan metode dan media pembelajaran yang kurang sesuai menjadi salah satu penyebabnya. Pembelajaran yang digunakan oleh guru pun juga masih banyak menggunakan ceramah, dan terpaku pada buku cetak dan LKS yang membuat suasana pembelajaran menjadi pasif, Siswa terlihat bosan dan kurang berminat mengikuti pembelajaran IPS. Hal ini juga dialami di kelas SDN Pakis V.

Media video pembelajaran IPS menjadi salah satu cara untuk mengatasi permasalahan yang terjadi di sekolah. Setelah media video diproduksi kemudian diuji cobakan kepada ahli media dan ahli isi/materi. Isi dari angket validasi adalah sebagai berikut:

1. Kejelasan materi dalam pelajaran IPS dengan menggunakan media video

2. Kelengkapan uraian materi dalam pelajaran IPS dengan menggunakan video

3. Kesesuaian video pembelajaran dengan materi

4. Kejelasan gambar video dan narasi dalam video pembelajaran

5. Kecepatan siswa memahami materi menggunakan video pembelajaran
6. Ketertarikan siswa belajar menggunakan video pembelajaran

7. Efisiensi pembelajaran dengan menggunakan video pembelajaran

8. Ketepatan penggunaan video pembelajaran pada pelajaran IPS

9. Kecenderungan siswa menggunakan video pembelajaran

10. Daya tarik susunan materi yang terdiri dari narasi, animasi video pembelajaran pada pelajaran IPS

Hasil dari pengembangan media video pembelajaran IPS kelas IV di SDN Pakis V secara keseluruhan dinyatakan valid. Terbukti dari hasil presentase uji coba ahli media sebesar 90,44\% dan hasil presentase dari ahli isi/materi adalah sebesar 93,44\%. Dari hasil presentase para ahli tersebut media video pembelajaran IPS yang di kembangkan sangat valid untuk digunakan dalam proses pembelajaran IPS di kelas IV.

Media video pembelajaran IPS kemudian diuji cobakan dengan cara memberikan kepada siswa kelas IV. Isi dari angket validasi siswa adalah:

1. Bagaimana kejelasan materi yang disampaikan melalui video pembelajaran?

2. Bagai mana isi materi dalam video pembelajaran?

3. Apakah kamu senang belajar menggunakan video pembelajaran ini?

4. Apakah gambar dan teks yang disajikan dalam video pembelajaran ini jelas?

5. Apakah gambar yang disajikan menarik?

6. Apakah belajar dengan menggunakan video pembelajaran ini memberikan motivasi mengikuti pelajaran IPS?

7. Apakah kamu menyukai video pembelajaran ini? 
8. Bagaimana perasaan kalian setelah belajar menggunakan video pembelajaran ini?

9. Apakah dengan bantuan video pembelajaran ini kamu lebih mudah memahami materi pelajaran IPS?

10. Menurut kamu apakah belajar menggunakan video pembelajaran menarik?

Hasil uji coba siswa perorangan diperoleh presentase 95\%. Hasil presentase uji coba kelompok kecil menunjukkan nilai $91,46 \%$. Sedangkan hasil uji coba kelompok besar/klasikal sebesar 90,50\%. Dari hasil presentasi siswa tersebut media pembelajaran IPS yang dikembangkan sangat valid digunakan dalam proses pembelajaran IPS di kelas IV. Meskipun secara keseluruhan pengembangan media video pembelajatan IPS ini dinyatakan valid digunakan dalam pembelajaran IPS di kelas IV SD, namun ada beberapa aspek yang harus direvisi sesuai dengan saran-saran yang diberikan para ahli pada saat validasi dilakukan.

Setelah selesai dilakukan uji coba validasi kepada para ahli dan uji coba siswa, kemudian dilanjutkan dengan pemberian tes akhir kepada siswa. Tes ini dilakukan untuk mengetahui keefektifan penggunaan media video pembelajaran IPS. Hasil tes yang diperoleh dari 36 siswa kelas IV memperoleh nilai rata-rata $90,75 \%$. Dari hasil nilai rata-rata yang diperoleh dapat disimpilkan bahwa para siswa telah memenuhi nilai KKM yang ditetapkan. Dengan demikian pengembangan media video pembelajaran IPS ini dinyatakan efektif digunakan dalam proses pembelajaran IPS di kelas IV.

\section{SIMPULAN DAN SARAN}

Keberadaan media pembelajaran sangat membantu guru dalam penyampaian materi pada proses pembelajaran, karena peran media pembelajaran adalah sebagai jembatan komunikasi antara guru dan siswa. Dengan demikian seyogyanya media pembelajaran perlu digunakan pada saat proses pembelajaran di dalam kelas. Pengembang melakukan pengembangan produk berupa media video pembelajaran IPS adalah sebagai bentuk strategi penyampaian pesan pembelajaran.

Saran yang disampaikan pengembang untuk pengembang selanjutnya adalah hendaknya proses uji coba validasi kepada para ahli dilakukan lebih dari sekali, agar produk yang dihasilkan benar-benar menarik baik dari segi tampilan maupun materi yang ada di dalamnya. Selain itu supaya produk yang dihasilkan juga lebih kreatif dan lebih menarik agar tidak terjadi kejenuhan para siswa dalam proses pembelajaran, khususnya pembelajaran IPS.

\section{DAFTAR RUJUKAN}

Anderson, Ronald H. 1987. Pemilihan dan Pengembangan Media untuk Pembelajaran. Jakarta: Universitas Terbuka bekerja sama dengan CV. Rajawali.

Arsyad, Azhar. 2001. Media Pembelajaran. Jakarta: Rajawali Press.

Daryanto. 2011. Media Pembelajaran. Bandung: Satu Nusa.

Ibrahim, dkk. 2005. Media Pembelajaran. Malang : Universitas Negeri Malang. 
Melinda, Vannisa Aviana, dkk. (2017). Pengembangan Media Video Pembelajaran IPS Berbasis Virtual Field Trip (VFT) Pada Kelas V SDNU Kraton-Kencong. JINOTEP, Volume 3, Nomor 2, April 2017.

Mukminan. 1996. The Wdining Horizon or Expanding Environment Curriculum. Diakses dari https://pgsd.binus.ac.id/2018/01/0 8/karakteristik-ips-di-sekolah$\underline{\text { dasar/ Pada tanggal } 20 \text { Desember }}$ 2019.

Prastowo, Andi. 2012. Panduan Kreatif Mambuat Bahan Ajar Inovatif. Yogyakarta: Diva Press.

Sadeli, Lili. M., dkk. 1986. Konsep Dasar Ilmu Pengetahuan Sosial Modul 1-3. Universitas Terbuka Jakarta. Diakses dari https://pgsd.binus.ac.id/2018/01/0 8/karakteristik-ips-di-sekolahdasar/ Pada tanggal 20 Desember 2019.

Sadiman, Arief. 2009. Media Pendidikan. Jakarta: PT. Raja Grafindo Persada.

Sapriya. 2009. Pendidikan IPS. Bandung: PT. Remaja Rosda Karya.

Smaldino, S.E., Lowther, D.L., \& Russel, J.D. 2008. Instructional Technology \& Media For Learning (Kesembilan ed). Terjemahan A. Rahman. 2011. Jakarta: Kencana. 